\title{
Analysis of 83 consecutive liver transplants performed at a tertiary care reference hospital in the interior of the State of Sao Paulo ${ }^{1}$
}

\author{
Analise de 83 transplantes hepáticos consecutivos realizados em hospital universitário de \\ referência terciária do interior do Estado de São Paulo
}

\begin{abstract}
Ana Carolina Lombardi', Enio David Mente" ${ }^{\mathrm{II}}$, Ajith Kumar Sankarankutty ${ }^{\mathrm{II}}$, Fernanda Fernandes Souza ${ }^{\mathrm{III}}$, Andreza Corrêa Teixeira $^{\text {III, Daniel Cagnolati }}{ }^{\mathrm{IV}}$, Maria Eliza Jordani de Souzav, Orlando de Castro e Silva Jr ${ }^{\mathrm{VI}}$

IUndergraduate Medical student and Monitor of the Digestive Surgery Division, Department of Surgery and Anatomy, FMRP-USP, Ribeirao Preto-SP, Brazil. Acquisition and interpretation of data, responsible for manuscript writing, statistical analysis.

IIPhD, Assistant Professor, Division of Digestive Surgery, Department of Surgery and Anatomy, FMRP-USP, Ribeirao Preto-SP, Brazil. Helped with technical procedures, collection and processing of study informations.

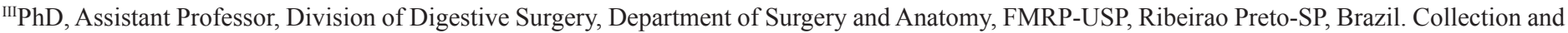
processing of study informations, helped with technical procedures, critical revision.

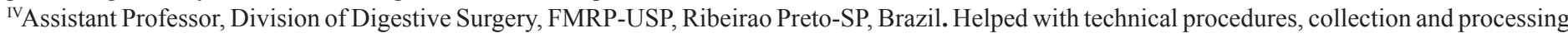
of study informations.

${ }^{\mathrm{v}}$ Master, Biochemistry, Division of Digestive Surgery, FMRP-USP, Ribeirao Preto-SP, Brazil. Acquisition and interpretation of data, statistical analisys. ${ }^{\mathrm{VI}}$ Chairman and Head, Division of Digestive Surgery, FMRP-USP, Ribeirao Preto-SP, Brazil. Helped with technical procedures, collection and processing of study informations, responsible for English language, critical revision.
\end{abstract}

\begin{abstract}
PURPOSE: To analyze pre-, intra- and immediate postoperative parameters of patients submitted to liver transplantation.

METHODS: Eighty-three consecutive orthotopic liver transplants performed from January 2009 to July 2011 were analyzed. The patients were divided into 2 groups: A, survivors (MELD between 9 and 60) and B, non-survivors (MELD between 14 and 40 ), with $30.6 \%$ of group A patients being CHILD C, 51\% CHILD B and 18,4\% CHILD A. In group B ,32.1\% of the patients were CHILD C, $42,9 \%$ CHILD B, and 25\% CHILD A. All orthotopic liver transplantations were performed using the piggyback technique without a portacaval shunt. Systemic arterial pressure and serum ALT and AST levels were determined preoperatively and 5, 60 and 1440 minutes after arterial graft revascularization. Serum ALT and AST profiles were evaluated for seven days after surgery.

RESULTS: Systemic arterial blood pressure levels, time of hot and hypothermic ischemia and time of graft implant were statistically similar for the two groups ( $>00.05)$. Serum levels (U/L) of ALT and AST at the 5, 60 and 1440 minute time points after arterial revascularization of the graft were also similar for the two groups studied, as also were the serum ALT and AST profiles.

CONCLUSIONS: No statistically significant difference in any of the parameters studied was detected between the two groups. Under the conditions of the present study and on the basis of the parameters evaluated, no direct relation was detected between the intraoperative period and the type of patient outcome in the two groups studied.
\end{abstract}

Keywords: Liver Transplantation. Transaminases. Blood Pressure.

\section{RESUMO}

OBJETIVO: Analisar parâmetros do pré, intra e pós-operatório imediato de pacientes submetidos ao transplante de fígado.

MÉTODOS: Foram analisados 83 transplantes ortotópicos de fígado realizados consecutivamente no período janeiro de 2009 a julho de 2011. Os pacientes foram dividos em dois grupos: A, survivors (MELD entre 16 e 60), e B, non-survivors (MELD entre 14 e 40 ) sendo que 30,6\% dos pacientes do grupo A eram CHILD C, 51\% CHILD B e 18,4\% CHILD A. No grupo B, 32, 1\% dos pacientes eram CHILD C, 42,9\% CHILD B, e 25\% CHILD A. Todos os transplantes ortotópicos de fígado foram feitos com a técnica de piggyback sem "shunt" porto cava. Foram analisados os valores de pressão arterial sistêmica e os níveis séricos de ALT e AST, no pré-operatório, 5, 60 e 1440 minutos após revascularização arterial do enxerto. Avaliaram-se os perfis séricos da ALT e AST durante sete dias de pós-operatorio.

RESULTADOS: Verificou-se que em ambos os grupos, os níveis de pressão arterial sistêmica, os tempos de isquemia normotérmica, hipotérmica e de implante do enxerto foram estatisticamente semelhantes ( $p>0,05)$. Os níveis séricos (U/L) de ALT e AST nos tempos de 5, 60 e 1440 minutos após a revascularização arterial do enxerto também foram semelhantes nos grupos estudados. Os perfis séricos da ALT e AST foram semelhantes nos dois grupos estudados.

CONCLUSÕES: Não se verificou diferença estatisticamente significante entre todos os parâmetros estudados, em ambos os grupos. Nas condições do presente estudo, não se verificou relação direta do intra-operatório com o tipo de evolução (outcome) dos pacientes nos dois grupos estudados.

Descritores: Transplante de Fígado. Transaminases. Pressão Arterial. 


\section{Introduction}

Patients with cirrhosis of the liver course with a hyperdynamic systemic circulation, manifested by an increased cardiac output and decreased peripheral vascular resistance and arterial pressure ${ }^{1}$. These changes intensify with disease progression and are reversible with liver transplantation. This surgical procedure is highly complex for the treatment of preventable diseases such as cirrhosis due to complications of hepatitis B virus and hepatitis $\mathrm{C}$ virus and alcohol-induced cirrhosis in $80 \%$ of cases $^{2}$. Patients submitted to a liver transplant have post-transplant 5-year survival rates ranging from 70 to $90 \% \%^{3-5}$.

Literature reports have shown a relation between systemic blood pressure levels and the type of postoperative outcome $^{1,4}$. Patients with low arterial blood pressure, due to the systemic vasodilation mentioned above, have a postoperative outcome involving greater morbidity and mortality. However, the data regarding this association are conflicting among authors, suggesting that, in reality, the postoperative complications of hypotense patients are due to a set of factors such as prolonged times of normothermic and hypothermic ischemia, quality of the donor and of graft preservation, presence of comorbidities, and stage of liver disease ${ }^{6-9}$. All of these factors may determine ischemia/reperfusion injuries in the recipient's liver that invariably determine different types of postoperative outcome.

The objective of the present study was to evaluate consecutive patients submitted to liver transplantation using biochemical exams of easy collection and laboratory determination, systemic arterial pressure levels, and surgical times to relate them to postoperative outcome.

\section{Methods}

We retrospectively analyzed 83 orthotopic liver transplants consecutively performed during the period from January 2009 to July 2011. The research protocol was approved by the Research Ethics Committee of the University Hospital, Faculty of Medicine of Ribeirao Preto. The patients were divided into 2 groups: A, survivors (MELD between 9 and 60), and B, nonsurvivors, (MELD between 14 and 40), with $30.6 \%$ of group A patients being CHILD C, 51.0\% CHILD B and 18.4\% CHILD A. In group $\mathrm{B}, 32.1 \%$ of the patients were CHILD C, $42.9 \%$ CHILD B, and $25.0 \%$ CHILD A. $78.3 \%$ of the patients were males and patient age ranged from 12 to 67 years (Table 1). All patients who died within the first 30 days after surgery were assigned to the nonsurvivor group. All orthotopic liver transplants were performed by the piggyback technique without a portacaval shunt. There was no intraoperative mortality during the study period. There were no cases of hepatic artery thrombosis or primary liver non-function. Systolic and diastolic systemic arterial pressure was measured approximately six hours before the beginning of surgery for liver transplantation and serum ALT and $\mathrm{AST}^{10}$ levels were determined preoperatively and 5, 60 and 1440 minutes after arterial graft revascularization. Serum ALT and AST profiles were evaluated for a period of seven days after surgery.

\section{Statistical analysis}

An unpaired Student $t$ test was used to compare differences between demographic and clinical data of patients. The values were reported as mean \pm standard deviation (SD). The level of significance was set at 0.05 . All statistical analyses were performed using SAS software version 9.2 (SAS Institute Inc., Cary, NC, USA).

\section{Results}

TABLE 1 - Demographic, clinical and etiologic data of patients submitted to ortothopic liver transplantation.

\begin{tabular}{lrr}
\hline Indicators (Patients=83) & Survivors & Non-survivors \\
\hline Patients (\%) & $63,9 \%$ & $36,1 \%$ \\
Average age & 49,7 & 51,7 \\
Gender & & \\
\hline Female & $18,9 \%$ & $26,7 \%$ \\
Male & $81,1 \%$ & $73,3 \%$ \\
CHILD & & \\
\hline A & $18,4 \%$ & $25,0 \%$ \\
B & $51,0 \%$ & $42,9 \%$ \\
C & $30,6 \%$ & $32,1 \%$ \\
MELD & & \\
\hline <16 & $8,2 \%$ & $7,4 \%$ \\
$16-30$ & $87,8 \%$ & $85,2 \%$ \\
>30 & $4,1 \%$ & $7,4 \%$
\end{tabular}

Systolic and diastolic arterial pressure levels were similar for the patients of the survivor and non-survivor groups ( $p>0.05)$, as shown in Figure 1. 


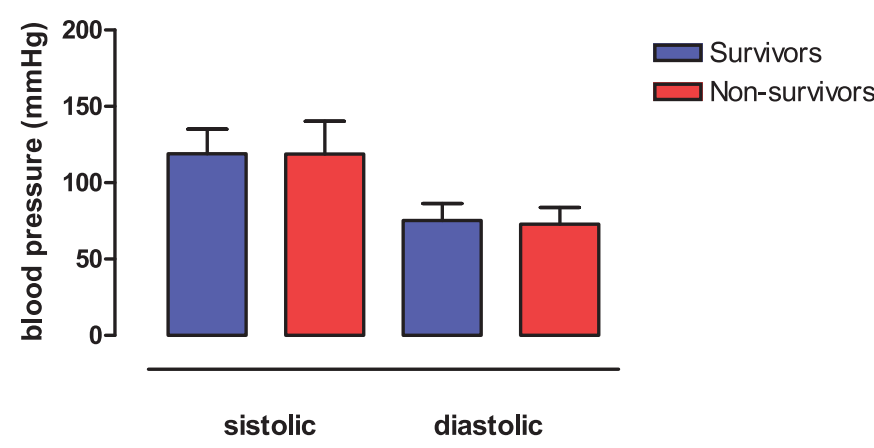

FIGURE 1 - Systolic and diastolic arterial pressure levels in patients of the survivors and non-survivors groups.

Aminotransferase (ALT and AST) levels at 5, 60 and 1440 minutes after revascularization were similar $(\mathrm{p}>0.05)$, as shown in Figure 2. There was no significant difference between the survivor and non-survivor groups $(\mathrm{p}>0.05)$

\section{A}

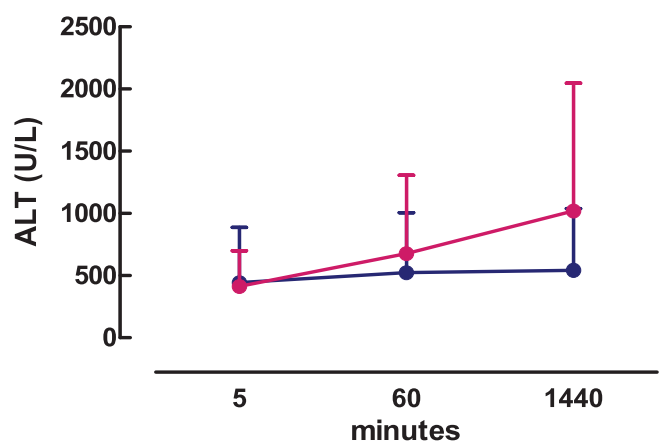

B

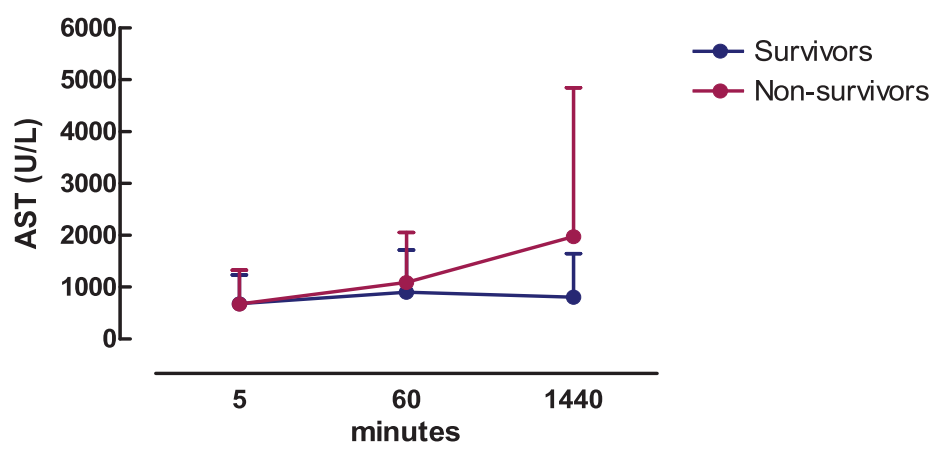

FIGURE 2 - Aminotransferase values, ALT (panel A) and AST (panel B), at 5,60 and 1440 minutes after arterial graft revascularization of patients of the survivor and non-survivor groups.

The Time of implant (minutes) was similar for the survivor and non- survivor groups $(\mathrm{p}>0.05)$ as shown in Figure 3.

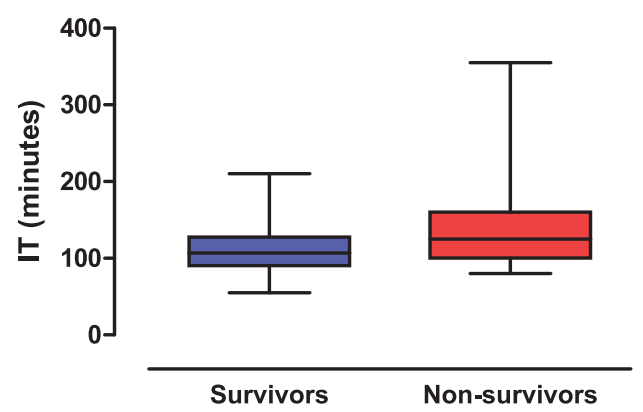

FIGURE 3 - Implant times for the patients of the survivor and nonsurvivor groups.

As shown in Figure 4, the times of normothermic ischemia (panel A) and hypothermic ischemia (panel B) were similar for the survivor and non-survivor groups $(p>0.05)$.

A

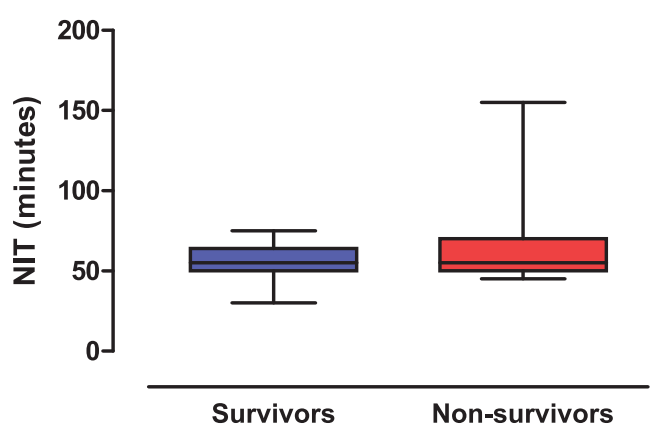

B

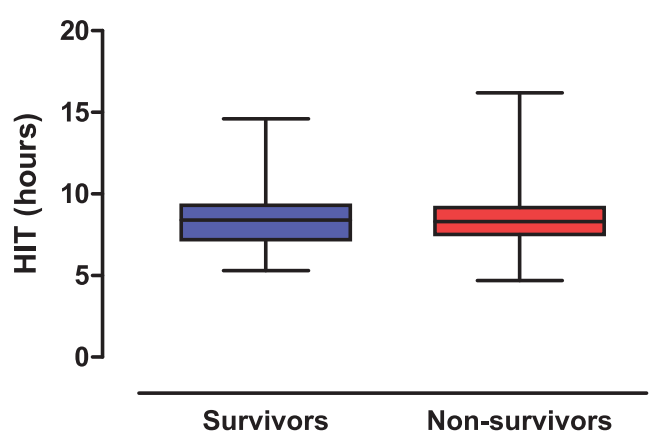

FIGURE 4 - Normothermic (panel A) and hypothermic (panel B) time for the patients of the survivor and non-survivor groups.

The serum aminotransferase profile, ALT (panel A) and AST (panel B), determined preoperatively and for seven days postoperatively was similar in the survivor and non-survivor groups ( $\mathrm{p}>0.05)$, as shown in Figure 5 . 

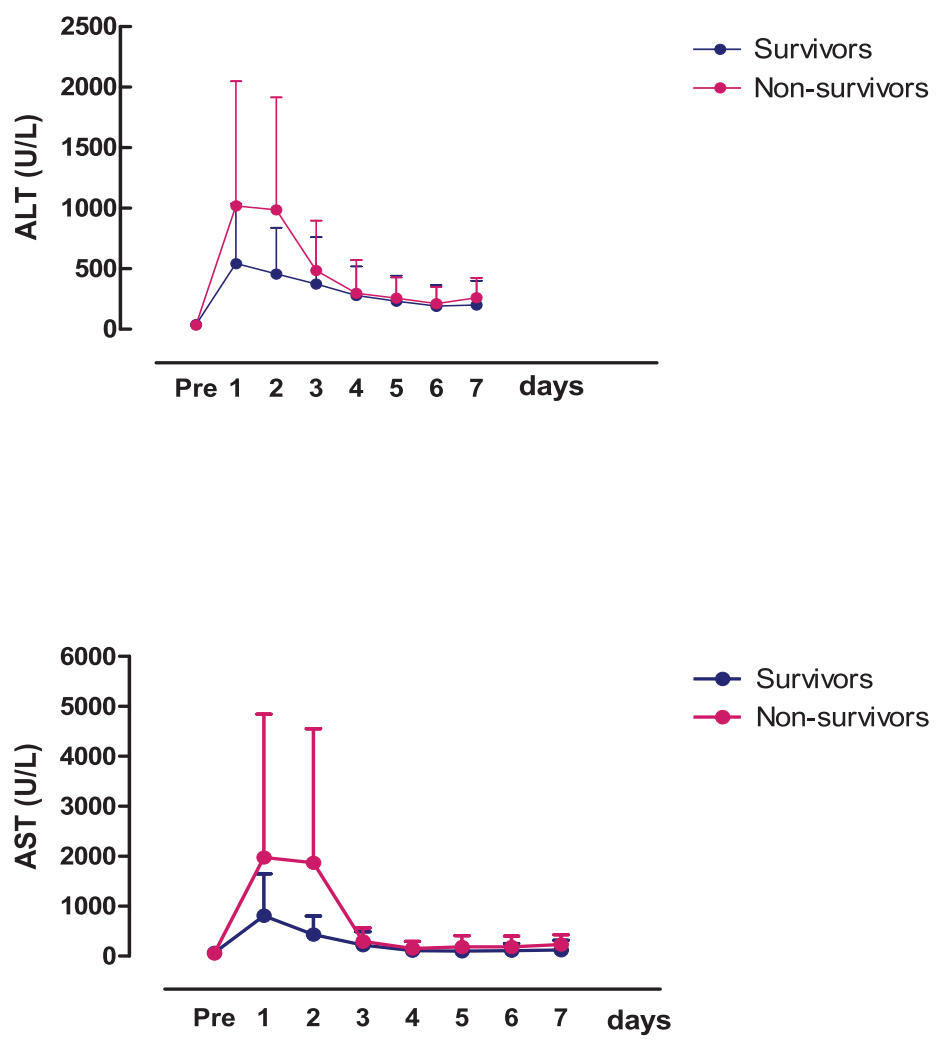

FIGURE 5 - Aminotransferase values, ALT (panel A) and AST (panel B), determined preoperatively and for seven days postoperatively were similar for the survivor and non-survivor groups.

\section{Discussion}

End-stage liver disease is one of the greatest public health problems all over the world. Cirrhosis is the main cause of indication of orthotopic liver transplantation (OLT) among adults, the most frequent etiologies being alcoholism and chronic hepatitis virus $A$ and hepatitis virus $B$ infection. With the refinements of the surgical technique, of intensive care and of the clinical management of continuous immunosuppression, patient survival tends to improve every year ${ }^{5,11-13}$.

OLT has a significant preoperative risk and the success of the procedure is due in part to appropriate selection of recipients from a medical, psychological and social viewpoint, to insure perfect patient adherence to the available medical care ${ }^{13,14}$.

Due to the severity of the disease and the scarcity of organs available for transplantation, especially in Brazil, many patients become worse or even die while on the waiting line. The ones who succeed in achieving transplantation invariably present more severe disease and therefore are likely to experience a higher rate of complications during the postoperative period ${ }^{15,16}$.

OLT has two basic objectives in the treatment of chronic liver disease: to prolong survival and to improve the quality of life of the patient, which gradually deteriorates due to the complications of the disease, such as ascites, upper digestive hemorrhage, encephalopathy, malnutrition, infection and so on. Based on the Child-Turcot Pugh (CTP) classification, it can be seen that the scores of patients on the waiting list increase while they wait for OLT7 ${ }^{13-15}$

Ideally, a liver transplant should be performed before the patients experience successive complications. However, the opportunity of OLT is difficult and the patients reach the time of operation in a much more serious situation than when they entered the waiting list. There still is no way to assess with precision the functional reserve of a cirrhotic liver or to predict the chances of survival of a recipient of a liver transplant. Several studies have been conducted in an attempt to find indicators that predict death or survival after $\mathrm{OLT}^{4,13,15}$. However, current indexes are unable to accurately predict which patients will have a high probability of posttransplant survival. For this reason, the search for a prognostic factor to predict early mortality of patients submitted to OLT still continues.

In the present study, we analyzed 86 consecutive transplants performed at a tertiary reference hospital over a period of approximately two years. The patients were divided into two groups, i.e., survivors and non-survivors. Two biochemical and clinical parameters of easy execution and of low cost were evaluated in order to determine eventual differences between groups.

Systolic and diastolic pressure levels were similar for the survivor and non-survivor groups. The arterial pressure considered was that measured at the time of patient admission, on average six hours before the anesthetic procedure for the transplant. It should be pointed out that the systemic pressure levels of the two groups were similar to normal values, also considering that all patients were chronically taking a beta-blocker in order to reduce portal pressure while waiting on the transplant line. These patients are known to have peripheral systemic vasodilation and increased cardiac output in a compensatory manner, a fact that seems to have been effective in these patients ${ }^{6,17,18}$.

The times of normal and hypothermic ischemia were similar for survivors and non-survivors, demonstrating that these times did not interfere significantly in the postoperative course. Prolonged times of ischemia, especially normothermic ischemia, are known to induce serious postoperative complications that may contribute directly or indirectly to death.

In the present study, ischemia and reperfusion injury, evaluated on the basis of serum aminotransferase levels at 5 and 60 minutes and four hours (1440 minutes) after arterial graft 
revascularization, was of low intensity in both groups. Ischemia/ reperfusion injury is directly related to prolonged times of ischemia, to the quality of the graft, the conditions of the donor, and the type of hypothermic preservation. The implantation time was also similar for the two groups, demonstrating that the intraoperative parameters did not interfere, in general, with postoperative outcome. In addition, the postoperative aminotransferase profiles did not discriminate between survivors and non-survivors despite higher mean ALT and AST levels with a greater dispersion of the values among non-survivors, explaining the absence of a significant difference between groups.

\section{Conclusions}

No significant difference in the parameters studied was detected between the two groups. Under the conditions of the present study and regarding the parameters evaluated, no direct relation was detected between the intraoperative period and the type of patient outcome in the two groups studied.

\section{References}

1. Gaskari AS, Honar H, Lee SS. Therapy insight: cirrhotic cardiomyopathy. Nat Clin Gastroenteol Hepatol. 2006;3:329-37.

2. Hunt CM, Tart JS, Dowdy E, Bute BP, Williams DM, Clavien PA. Effect of orthotopic liver transplantation on employment and health status. Liver Transpl Surg. 1996;2:148-53.

3. Yao FY, Saab S, Bass NM, Hirose R, Ly D, Terrault N, Lazar AA, Bacchetti P, Ascher NL, Roberts, JP. Prediction of survival after liver retransplantation for late graft failure based on preoperative prognostic scores. Hepatology. 2004;39:230-8.

4. Raszeja-Wyszomirska J, Wasilewicz MP, Wunsch E, Szymanik B, Jarosz K, Wójcicki M, Milkiewicz P. Assesment of modified Chol-Pugh-Turcotte score to predict early mortality after liver transplantation. Transplant Proc. 2009;41:3114-6.

5. Charlton MR, Burns JM, Pedersen RA, Watt KD, Heimbach JK, Dierkhising RA. Frequency and outcomes of liver transplantation for nonalcoholic steatohepatitis in the United States. Gastroenterology. 2011. [Epub ahead of print].

6. Algahtani SA, Fouad TR, Lee SS. Cirrhotic cardiomyopathy. Semin Liver Dis. 2008;28:59-69.

7. Ruf AE, Kremers WK, Chavez LL, Descalzi VI, Podesta LG, Vilamil FG. Addition of serum sodium into the MELD score predicts waiting list mortality better than MELD alone. Liver Transpl. 2005;11:33643.

8. Boker KH, Dalley G, Bahr MJ, Maschek H, Tillmann HL, Trautween C, OldhaverK, Bode U, Pichlmaur R, Manns MP. Long-term outcome of hepatitis $\mathrm{C}$ virus infection after liver transplantation. Hepatology. 1997;25:203-10.

9. Bravata DM, Olkin I, Barnato AE, Keeffe EB, Owens DK. Healthrelated quality of life after liver transplantation: a meta-analysis. Liver Transpl Surg. 1999;5:318-31.

10. Henry RJ, Chiamori N, Golub OJ, Berkman S. Revised spectrophotometric methods for the determination of glutamicoxalacetic transaminase, glutamic-pyruvic transaminase, and lactic acid dehydrogenase. Am J Clin Pathol. 1960;34:381-98.

11. Gross CR, Malinchoc M, Kim WR, Evans RW, Wiesner RH, Petz JL, Crippin JS, Klintmalm GB, Levy MF, Ricci P, Therneau TM, Dickson ER. Quality of life before and after liver transplantation for cholestatic liver disease. Hepatology. 1999;29:356-64.

12. Neff GW, O'Brien CB, Nery J, Shire NJ, Nishida S, delaGarza J, Montalbano M, Safdar K, Ruiz P, Rideman E, Gascon JA, Tzakis AG, Madariaga J, Rudich SM. Factors that identify survival after liver retransplantation for allograft failure caused by recurrent hepatitis C infection. Liver Transpl. 2004;10:1497-503.

13. Huo TI, Lee SD, Lin HC. Selecting an optimal prognostic system for liver cirrhosis: the model for end-stage liver disease and beyond. Liver Int. 2008;28:606-13.

14. Desai HG. Does model for end-stage liver disease (MELD) require modification? J Assoc Physicians India. 2011;59:372-3.

15. Basile-Filho A, Nicolini EA, Auxiliadora-Martins M, AlkminTeixeira GC, Martinez EZ, Martins-Filho AO, Castro e Silva Jr O. Comparison of acute physiology and chronic health evaluation II death risk, Child-Pugh, Charlson, and model for end-stage liver disease indexes to predict early mortality after liver transplantation. Transplant Proc. 2011;43:1660-4.

16. Milan Z, Taylor C, Duncan B, Kedilaya H, Sylvester D. Statistical modeling of hemodynamic changes during orthotopic liver transplantation: predictive value for outcome and effect of marginal donors. Transplant Proc. 2011;43:1711-5.

17. Desai MS, Zainuer S, Kennedy C, Kearney D, Goss J, Karpen SJ. Cardicac structural and functional alterations in infants and children with biliary atresia, listed for liver transplantation. Gastroentereology. 2011 [epub ahead of print].

18. Lee RF, Glenn TK, Lee SS. Cardicac dysfunction in cirrhosis. Best Pract Res Clin Gastroenterol. 2007;21:125-40.

\section{Correspondence:}

Orlando Castro e Silva Junior

Rua Campos Salles, 890/92

15015-110 Ribeirão Preto - SP Brasil

Tel.: (55 19)3602-2242

orlando@fmrp.usp.br

Received: May 25, 2011

Review: July 26, 2011

Accepted: August 29, 2011

Conflict of interest: none

Financial source: none

${ }^{1}$ Research performed at Department of Surgery and Anatomy, Ribeirao Preto School of Medicine, University of Sao Paulo (FMRP-USP), Brazil.

Presented at the XII National Congress on Experimental Surgery of the Brazilian Society for the Development of Research in Surgery-SOBRADPEC 2011, October 26-29 Ribeirao Preto-SP, Brazil. 